\title{
Financial Crisis and Firm Performance: empirical evidence from Turkey
}

\section{Halit Gonenc* and C. Bulent Aybar}

The objective of this study is to examine the impact of concentrated ownership and business group affiliation on the performance of Turkish firms during the financial crisis by controlling balance sheet currency exposure, international involvement and firm size. Our analysis focuses on a 12-month window encapsulating the February 2001 financial crisis. Our findings show that balance sheet exposure is the key determinant of the firm performance during the crisis periods. While we find evidence that firms with higher concentrated ownership experience lower stock market performance prior and during the financial crisis, business group affiliation does not have any impact on the performance. However, there is weak evidence that stock market performance increases with the level of business group diversification.

Keywords: Financial crisis, firm performance, exchange rate exposure, concentrated ownership, business groups, group diversification, emerging market

\section{Introduction}

$\mathbf{R}$ ecent studies point to the significance of corporate governance in stock market performance during financial crises in emerging markets (Johnson et al., 2000; Mitton, 2002; Lemmon and Lins, 2003). Corporate governance is the protection of outside investors against insider expropriation. Aggressive expropriation both by managers and controlling shareholders is particularly important for emerging markets, because emerging markets typically suffer from low investor protection practices. Particularly, when return expectations lingered, insider expropriation in these markets accelerates (Johnson et al., 2000). Therefore, consideration of corporate governance may provide additional insights in investigations of stock return performance, especially during a financial crisis.

The objective of the current study is to analyse the impact of a financial crisis on the exchange listed non-financial Turkish firms. The Turkish economy experienced a massive currency crisis when its crawling peg regime collapsed on 21 February 2001. Within the course of two days, the Turkish Lira devalued as much as 31 percent against the US dollar. The currency crisis quickly spiralled into a systemic financial meltdown and the Turkish economy contracted by 10 percent in 2001 . The prolonged recession dragged until the economy recovered in 2003. This period provides the context for our study. We analyse the impact of this large currency value depreciation on the firm performance by focusing on two dominant corporate governance factors; fraction of shareholders, who have control on management, and affiliation of firm with a business group. In this analysis, we control firm balance sheet currency exposure and degree of international involvement as significant determinants of firm performance.

Unlike the conventional exposure studies, we use two proxies for currency exposure: Total exposure and debt exposure. Total exposure is defined as the ratio of net balance sheet exposure (difference between the Turkish Lira
*Address for correspondence: Faculty of Management and Organization, University of Groningen, P.O. Box 800, 9700 AV Groningen, The Netherlands. Tel: +31 (0)50 3637082 ; Fax: +31 (0)50 363 3850; E-mail: h.gonenc@rug.nl 
(TL) value of foreign currency denominated assets and liabilities) to total assets. The debt exposure is defined as the ratio of the TL value of foreign currency denominated debt to total debt. With such exposure measures, this study focuses on a 12-month time window around the February 2001 financial crisis. We argue that firm-specific operational, governance and corporate structure characteristics contribute to a better understanding of the impact of the currency crises on the firm performance in the emerging market context. Furthermore, we expect that currency exposure proxies employed in our analysis provide a superior gauge for the firm-specific risks as compared to operational exposure coefficients.

Our results indicate a negative exposure for the total balance sheet measure regardless of the industry, export or import orientation. This suggests that foreign currency denominated liabilities on average exceed foreign currency denominated assets. Consistent with previous literature first, we show that there are differences in firm performance during the Turkish currency crisis. In particular, concentrated ownership is associated with significantly poorer stock price performance. This is consistent with Johnson et al. (2000) and Lemmon and Lins' (2003) fund expropriation argument. These authors suggest that the expected amount of expropriation can be relatively larger in countries where legal protection of investors is lower when times are worse. Second, our findings do not indicate a performance difference between affiliated and nonaffiliated firms. We also find weak evidence to support the association between firm performance and the degree of group diversification during the financial crisis. For large firms, firms with relatively higher export sales, relatively smaller negative exposure and positive total exposure, our study reveals larger excess dollar returns prior to crisis and in the crisis month.

The rest of this paper is organised as follows: in the next section we provide a brief background on the Turkish currency crisis, after which we evaluate the extant literature, discuss the findings reported in related studies and explore the currency exposure in the Turkish context. We introduce our data and methodology before discussing our empirical findings. We conclude the paper with final remarks.

\section{A brief review of the Turkish financial crisis}

When the Turkish government announced its 17th stabilisation programme in December
1999, approximately 14 months prior to the February 2001 crisis, severely deteriorated macroeconomic imbalances suggested that the perceived political risk of maintaining the status quo at the time was much higher as compared to previous periods. In its stabilisation programme, the government was proposing a comprehensive and far-reaching economic programme which addressed Turkey's many economic ills in the context of a Stand by Agreement with IMF. The letter of intent sent to the IMF on 9 December 1999 emphasised that the Turkish programme rested on three pillars: up-front fiscal adjustment, structural reforms and an exchange rate commitment. Clearly, had the programme achieved its objectives, it could invigorate the Turkish economy.

The new programme started a flurry of actions by the ruling coalition. The government diligently followed the reform agenda at the outset. A set of tight fiscal and monetary policies, the privatisation drive and a scheduled devaluation path for the Turkish Lira helped to bring interest rates and inflation to the lowest levels in years. However, during the second half of 2000, the initial momentum was lost. The decelerating reforms heightened the concerns about the viability of the disinflation programme and increased the market's sensitivity to bad news. The concerns further escalated after the collapse of ten private banks. The investigation of these banks under the control of the newly established Banking Regulation and Supervision Agency revealed massive corruption. Naturally, the reports aggravated the fear of a wider banking crisis. The ensuing sell off of Turkish treasury bills by foreign investors triggered a sudden capital outflow and created a massive liquidity pressure in the money markets. The Central Bank stopped providing liquidity to the market to avoid violation of the limits set by the Stand by Agreement for the net domestic assets. The increasing cost of overnight borrowing provoked fire sale of government bonds by one of the commercial banks with a very risky bond portfolio. Consequently, the bank was taken under the control of the Banking Supervisory Board on 5 December. The markets could only be calmed after the announcement of a US\$7.5 billion additional IMF credit. This was the first stress test for Turkey's fragile disinflation programme based on a crawling peg system. In the aftermath of the crisis, interest rates remained significantly higher than the preNovember 2000 levels.

The sustainability of the disinflation programme with a crawling peg became increasingly suspect as the Turkish Lira showed clear signs of substantial real appreciation. In result, 
export growth declined dramatically. Market scrutiny of the ailing attributes of the Turkish economy heightened despite the swift injection of a large-scale IMF credit. In the midst of all this adversity, Turkey tripped on its weak peg when a political clash between the prime minister and the president ignited a speculative attack on the Lira. Shortly after the eruption of the crisis, Central Bank abandoned the crawling peg and floated the Turkish Lira. This was the sign that, despite its "intellectually elegant" design with a built-in disintegration mechanism, the peg had failed. Turkey became the fifth high-profile victim of a currency peg after Mexico, Thailand, Russia and Brazil. The result was a huge cost on the Turkish economy in terms of lost monetary credibility, significant balance sheet deterioration and more importantly a very deep contraction.

\section{Currency crises, corporate governance and exposure}

\section{A review of recent literature}

Calvo and Reinhart (2000) point to severity of currency crises in emerging markets in contrast to developed countries. Forbes (2002) and Desai et al. (2003) show that firms with international activities are more affected by currency depreciations regardless of their origin. Glen (2002) examines stock returns over a 2year window surrounding 24 currency devaluations in emerging markets. He concludes that stock returns decline in the 6 months leading to the devaluation, but the returns following the devaluation vary across countries and firms depending on the firm, industry and country characteristics. The study reveals the significance of country and industry effects, as there is only limited support for the impact of firm-specific factors. The conclusion about the firm-specific factors may be influenced by the use of only a small number of variables such as size, liquidity and price/book value ratio. The author recognises the limitation as he calls for further research to explain the vast crosssectional variation observed in his sample.

A group of new studies focuses on the impact of financial crises on firm performance. This strand of literature reveals that various aspects of corporate governance may explain cross-sectional variation observed in firm performance. Johnson et al. (2000) emphasise the exacerbating effect of investors' perception of inappropriate expropriation during downward economic cycles. This effect may be stronger in emerging markets since in those controlling shareholders are also managers.
Johnson et al. provide a summary of alleged incidents where controlling shareholders might have unfairly expropriated value from creditors and minority shareholders in Asian countries. They then argue that weak enforcement of shareholders right has the first-order importance as compared to standard macroeconomic variables in determining the extent of exchange rate depreciation and stock market collapse in the 1997-98 Asian Crisis.

Mitton (2002) draws attention to three attributes of corporate governance (disclosure quality, ownership structure and corporate diversification) and their influence on the stock price performance of firms during the crisis. Her findings indicate the effect of large non-managing shareholders on superior stock performance. In contrast, corporate diversification has an opposite effect on the stock price. In her study the linkage between ownership concentration and performance is mainly attributed to prevention of expropriation in the case of concentrated ownership. The negative effect of diversification is attributed to increasing information asymmetry in highly diversified firms.

Similarly, Lemmon and Lins (2003) find a variation in firm performance based on differences in ownership structure during the East Asian financial crisis. In their view, the crisis period represents a negative shock to the investment opportunities of firms. Accordingly, in such periods there are more incentives for controlling shareholders to expropriate from minority shareholders. Also their study underlines the lower cumulative stock returns of firms with pyramid ownership structures during the crisis periods. Specifically they point to a significant return discount associated with the insider-controlled firms in which managers and their families detach the control and cash flow rights through pyramid structures. The authors conclude that corporate ownership structure plays an important role in determining the incentives of insiders to expropriate from minority shareholders during times of declining investment opportunities.

Baek et al. (2004) examine the relationship between corporate governance and firm value during the Korean financial crisis. They concur on the effect of specific corporate governance indicators and their effect on firm value. They also report that firms with concentrated ownership by affiliated firms experience a larger decline in equity value. A similar effect pertains to highly diversified firms with high leverage, as well as small and risky firms. ${ }^{1} \mathrm{Kim}$ and Lee (2003) find that ownership structure significantly explains performance of Korean firms during the crisis, especially for Cheabol firms. 


\section{Currency exposure in the Turkish context}

In this study, we analyse non-financial companies listed in the Istanbul Stock Exchange (ISE). As in many emerging market economies, the Turkish capital market displays the characteristic of an infant market. Indeed, the role of the equity markets in capital allocation is rather limited. ${ }^{2}$ There is no active corporate bond market. ${ }^{3}$ Chronic and extensive budget deficits compel governments to rely on borrowing from the domestic debt markets crowding out private borrowers from the bond markets. On the equity side, listed shares represent a relatively small portion of the industrial base. Primary and secondary markets lack institutional investors. Secondary markets suffer from thin trading as well as inadequate disclosure. Such deficiencies limit firms' ability to obtain external financing while increasing reliance on retained earnings and internal capital markets.

As in other emerging markets, minority shareholder protection in the Turkish equity markets is at best weak. ${ }^{4}$ Many listed firms exhibit highly concentrated ownership structures. Such structures, as Shleifer and Vishny (1997) point out, may be useful to alleviate agency problems between the firm management and outside investors. The shareholders establish better monitoring mechanisms on management and avoid many unfavourable decisions. On the other hand, concentrated ownership may lead to exploitation of minority shareholders. To investigate this conjecture, La Porta et al. (1998), with a sample of large firms from 49 countries, study the correlation between concentrated ownership and quality of protection of investors. Their findings show a strong negative correlation between the combined stake of the three largest shareholders and the quality of legal protection of investors. In adverse external conditions, as is argued by Johnson et al. (2000) and Lemmon and Lins (2003), the expected amount of expropriation tends to be larger. Accordingly, the effect of financial crisis would be exacerbated for the firms with a high percentage of concentrated ownership.

In Turkey, the majority of the large firms are organised as holding companies and they operate in the form of business groups similar to Korean Chaebols. Typically, holding companies own a bank which serves, directly or indirectly, as a major financial source for the member companies. This intertwined relation often leads to the creation of a well-organised internal capital market. By pooling their funds, group firms can collectively finance their short- and long-term capital requirements. These linkages facilitate access to capi- tal for firms affiliated with a business group. Plausibly this should reduce firm-level risk because of availability of funds through internal markets. Especially when capital sources dried out and interest rates surged, affiliated firms are less likely to be affected from the meltdown. In result, group affiliation alleviates the impact of the financial crises.

Chronic macroeconomic instability and persistent high inflation in the Turkish economy invariably create anomalies in the financial markets. Periodic overvaluation of the Turkish Lira under a variety of exchange rate regimes is a case in point. ${ }^{5}$ Additionally, large government sector borrowing keeps real interest rates consistently high and provides firms an incentive to seek arbitrage opportunities between domestic and foreign debt markets. In fact, during the Turkish Lira overvaluation, borrowing in foreign currency has been a standard strategy for many Turkish financial institutions and businesses regardless of their asset composition and revenue structures. While the resultant capital inflows deteriorate the domestic macroeconomic balances, the same channel also initiates the correction process. In several episodes, notably in 1994 and 2001, these corrections were sharp and highly disruptive, sending the economy into a full tailspin. Against such a macroeconomic backdrop, it is plausible to suggest that balance sheet exposure of the Turkish firms is critical in analysis of the impact of sharp depreciations. An important consideration that cannot be ignored in this context is the export and import activities of the firms. While firms with extensive export revenues in hard currencies have a natural hedge against their foreign currency denominated liabilities, firms with significant import bills face an increasing exposure to exchange rate movements. In an effort to differentiate the impact of depreciations/devaluations on the performance of firms with and without natural hedges, we take the import and export intensity of the firms into consideration.

\section{Data and methodology}

In this study we analyse performance of 198 Turkish industrial firms listed in the ISE by focusing on the 12-month period around the February 2001 financial crisis (from August 2000 to August 2001). The charts in Figure 1 provide a long-term visual on the movements of nominal and real exchange rates and selected stock market indices. The sharp devaluation of the Turkish Lira and the impact of the financial crisis on the equity prices are evident in the charts. Figure 1c also shows that 

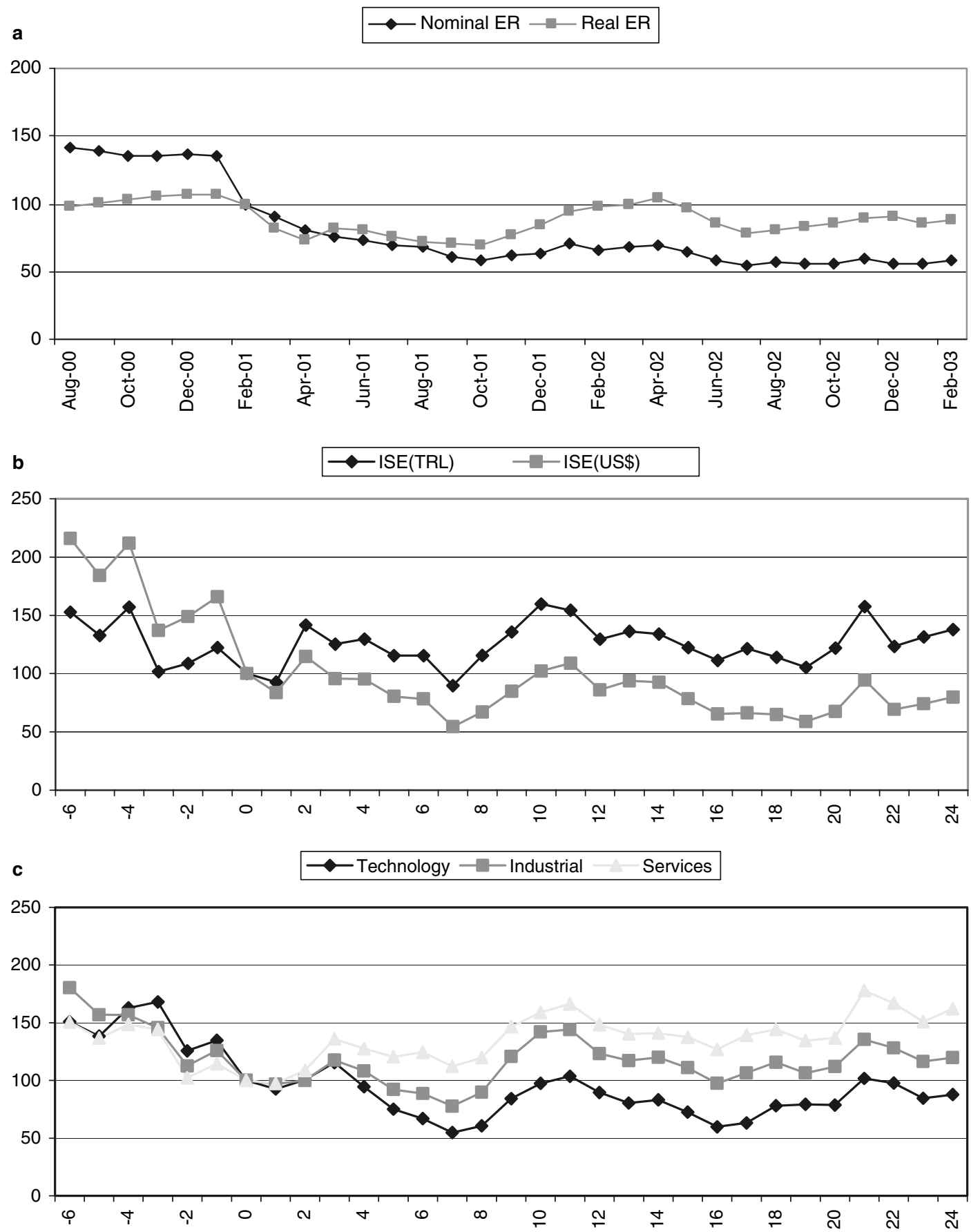

Figure 1: This figure presents a longer-term view of: movements of nominal and real exchange rate (a), of the stock market indices (b) and of some sector indices (c) to events surrounding devaluation event of Turkish Lira in February 2001. All indices are normalized to 100 on the month of devaluation

there might be industrial differences for the impact of financial crisis.

We deliberately excluded financial institutions (banks, mutual funds, investment and insurance companies) from the analysis because of their distinct financial and operational characteristics. The majority of the price and balance sheet data used in this study is drawn from the ISE database. Financial tables published by the ISE include detailed footnotes. Our firm-level balance sheet foreign currency exposure data were compiled from these footnotes. The listed companies report their foreign currency denominated assets and liabilities in footnote 30 of the published financial statements. 
We use market index adjusted holding period returns in US dollars for various horizons as a performance proxy. For each firmadjusted holding period returns are calculated by subtracting holding period returns of the market index from the firm-specific holding period returns:

$$
\operatorname{Ret}_{i}^{\$}\left(T_{1}, T_{2}\right)=R_{i, T_{1}, T_{2}}^{\$}-R_{m, T_{1}, T_{2}}^{\$}
$$

where $\left(T_{1}, T_{2}\right)$ is the holding period, $R_{i}$ is the return over the holding period in US dollars for firm $i$, and $R_{m}$ is the return for the market index over the holding period in US dollars.

Four alternative holding periods are used. $\operatorname{Ret}(0,0)$ is return in the crisis month, February 2001. $\operatorname{Ret}(-6,0)$ is return 6 months prior to and including the financial crisis month. $\operatorname{Ret}(0,+6)$ is the 6 months return following the crisis (including the crisis month). Ret $(-6,+6)$ is return encompassing 12 months around the crisis.

$Q$ is the ratio of market value of assets to book value of assets by two quarters prior to and after March 2001.

$$
Q_{i}=\frac{M V_{i}}{B V_{i}}
$$

We also measure $Q$ for three alternative periods. $Q(0,0)$ is for the financial crisis month. Since monthly balance sheet information is not available, we have to rely on quarterly information. Therefore $Q(0,0)$ is calculated by using market and book value of assets at the end of March 2001, which is around one month later than the financial crisis month. $Q(-6,0)$ and $Q(0,6)$ are calculated two quarters prior to and after March 2001.

We use two measures of balance sheet exchange rate exposure: (i) Total exposure is measured as the ratio of the difference between TL value of foreign currency denominated assets and TL value of foreign currency denominated liabilities to total assets at the end of the year 2000, which is the fiscal year end prior to the financial crisis month:

$$
\operatorname{TOTEXP}_{i}=\frac{\mathrm{FA}_{i, T K L}-\mathrm{FL}_{i, T K L}}{\mathrm{TA}_{i, T K L}}
$$

where FA is the TL value of foreign currency denominated assets, FL is the TL value of foreign currency denominated liabilities and TA is TL value of total assets.

(ii) Debt exposure is measured as the ratio of TL value of foreign currency denominated liabilities to total debt at the end of the year 2000.

$$
D E X P_{i}=\frac{\mathrm{FL}_{i, T K L}}{\mathrm{TL}_{i, T K L}} .
$$

Our empirical strategy is focused on the impact of percentage of shares held by controlling shareholders (concentrated ownership) and business group affiliation on the firm performance during and around the crisis period. However, first we conduct a range of differences in mean (median) values of performance and exposure variables to gain insight about the sample characteristics. The mean (median) values of selected variables were compared and the significance tests conducted by using $t$ (chi-square) statistics. In the second stage of our analysis we use a multivariate regression model to identify the determinants of crossfirms performance during crisis. Our multivariate regression model is stated below:

$$
\begin{aligned}
& \text { Performance Measures } \\
& =\alpha_{0}+\alpha_{1} \text { (Affiliation Dummy) } \\
& +\alpha_{2} \text { (Total Exposure) } \\
& +\alpha_{3} \text { (Export Sales Ratio) } \\
& +\alpha_{4} \text { (Import Cost Ratio) } \\
& +\alpha_{6}(\text { Debt Exposure })+\alpha_{6}(\text { Size }) \\
& +\alpha_{7} \text { (Concentrated Ownership) } \\
& +\sum \text { Industry Dummies + Error. }
\end{aligned}
$$

Affiliation dummy is used to classify firms depending on their connection with a business group (the value 1 designates affiliation with a business group). We use the ratio of export sales to total net sales and the ratio of import costs to total cost of goods sold as proxies for the extent and nature of international involvement of the firms. Natural logarithm of total assets at the end of the year 2000 controls the size of firms. Concentrated ownership is measured as the percentage of shares held by the largest three shareholders at the end of 2000. Dummies for major industries (the names of these industries are listed in Table 1) are used to control the industry effects.

\section{Empirical findings}

\section{The role of total exposure}

In Table 1, we report sample descriptive statistics by industry including number of observations, the percentage of concentrated ownership, mean balance sheet exposures (total and debt exposures), asset size, export and import ratios, holding period returns, and shares. The shares denote the percentage of the total firm shares actively traded on the market. 


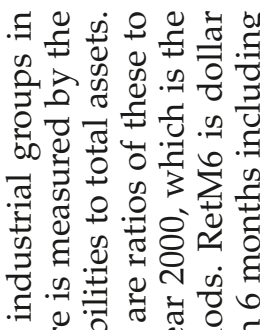

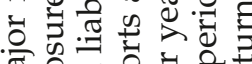

ब.

ช

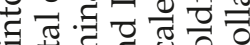

응 등 다

$\theta \in$

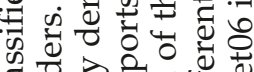

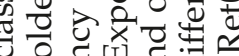

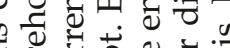

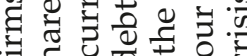

का 0

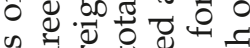

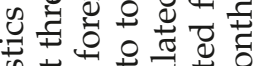

की

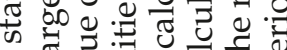

क

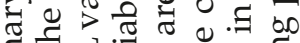

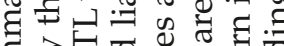

द्gि

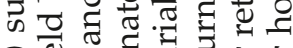

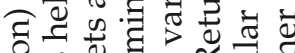

正舟

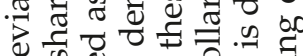

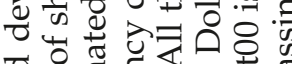

马.

त्र 80 है

든월

क⿺辶

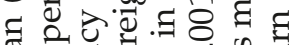

『 ष

क ज्ञ

כ च

害

雨.

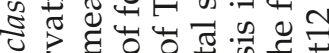

उ.

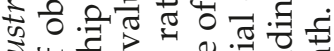
₹ ¿

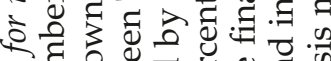

:

要

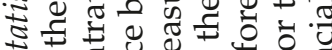

के

공 동. 의

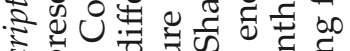

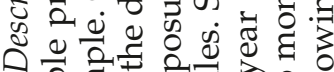

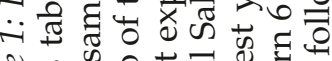
$\checkmark$.

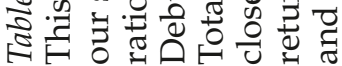

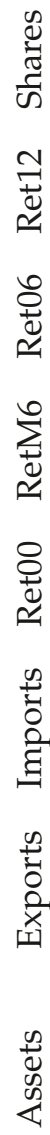

๗

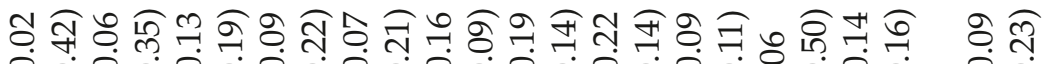

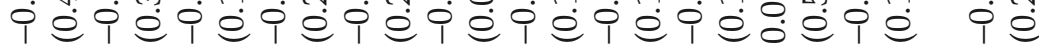

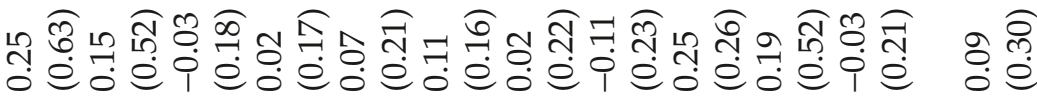

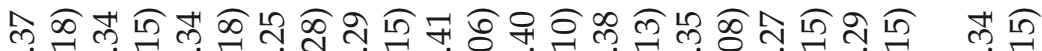

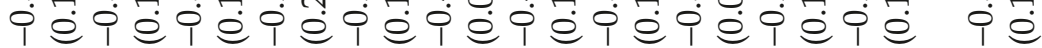

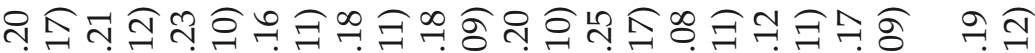

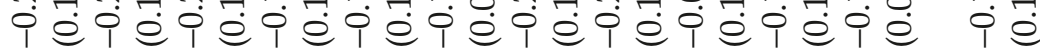

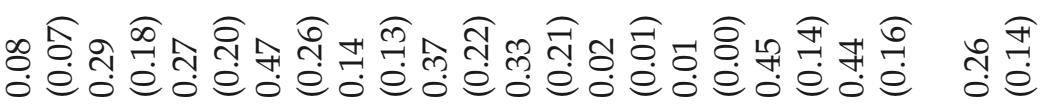

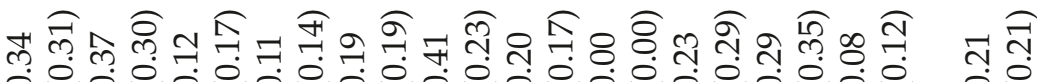

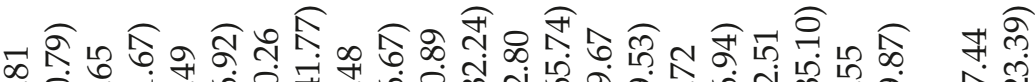

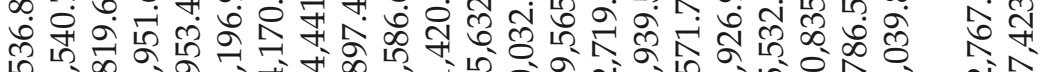
ले

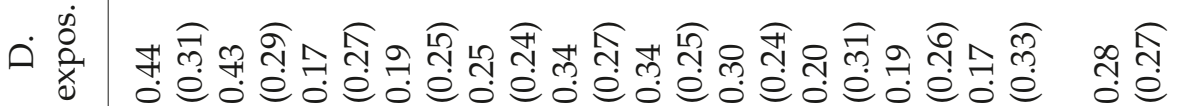

Hi

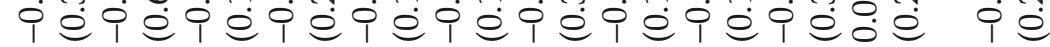

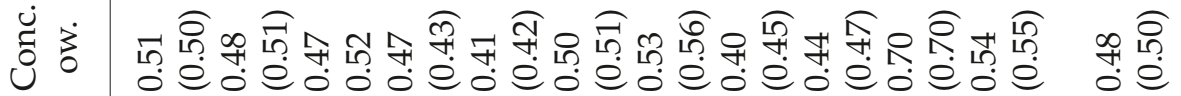

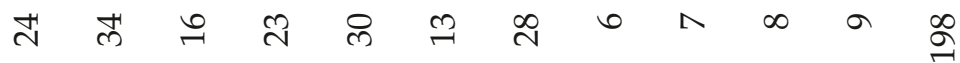

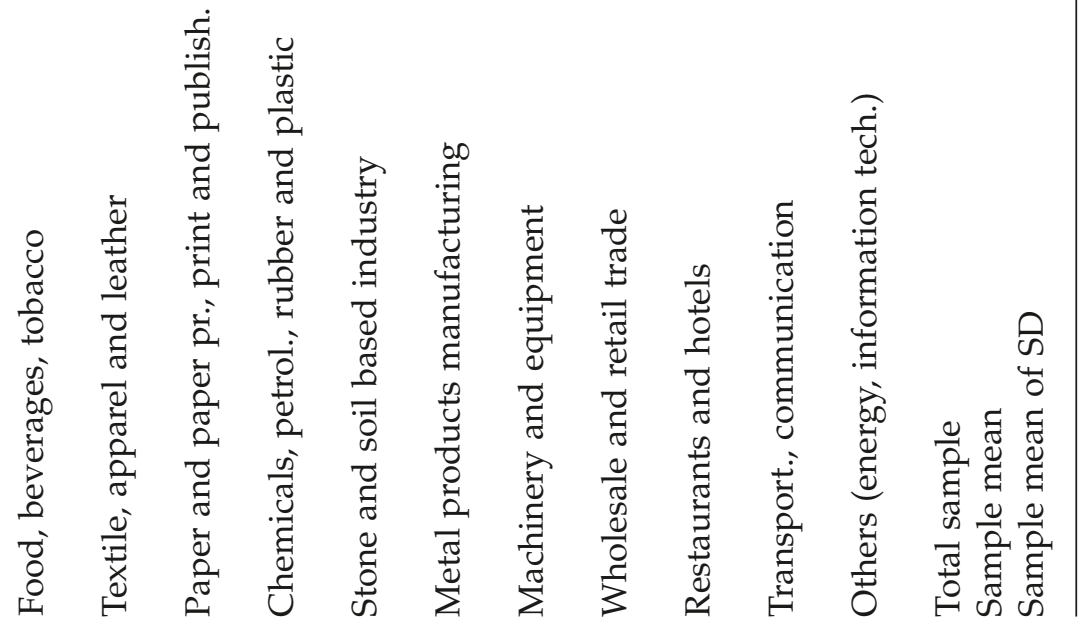


The findings reported in Table 1 suggest that 50 percent of firms' equity, on average, is held by three owners who have the largest percentage of shares. This does not change across industries, except transportation and communication industry. All industries on average exhibit negative balance sheet exchange rate exposures. Included in the list of higher balance sheet exposure are food/beverages/ tobacco, textile/clothing/leather, chemicals/ petroleum/rubber/plastic, material construction. Interestingly, export-oriented sectors such as textile and material construction have the highest negative exposures. An ad hoc explanation for this finding is that these companies may prefer to borrow in hard foreign currencies to finance their export sales particularly during Turkish Lira overvaluation. Ex ante, these liabilities are expected to be covered with export sales denominated in hard currencies, and provide a natural hedge for the firm. Hence, exporting firm's foreign currency debt preference is intuitive, particularly during the high real interest periods in the local debt markets. ${ }^{6}$

Mean returns in February 2001 and average holding returns for 6 month prior to the crisis are negative and range from -12 percent to -41 percent. A casual look at the average industry holding period returns suggests notable differences across industries. This observation requires verification, but it also suggests that we have to control for industry effects.

In general, export-oriented companies are expected to benefit from depreciation of their home country currencies. ${ }^{7}$ In contrast, importing companies benefit from the appreciation of their home currencies. Also exporters with larger foreign currency denominated debt than their foreign currency denominated assets (negative total exposure) benefit from an appreciation of the home currency. At the same time they face increasing debt service costs in the wake of a depreciation, which may not be offset by the increasing export revenues. Hence, we argue that balance sheet exchange rate exposure is more important than the form and international activities of the firms in determining the exchange rate risk. We develop our analysis to control balance sheet currency exposure in the examination of how firms with varying corporate governance characteristics are affected from the financial crisis.

\section{Corporate governance and comparative performance analysis}

In Table 2, we present a summary of mean values of stock performance (holding period returns and the $Q$ ratio) for the sample and for two different classifications. First, the mean (median) value of stock returns (Ret00) for the sample firms is $-0.19(-0.20)$ in the crisis month. Six months before the crisis (RetM6), the mean (median) stock return is -0.34 $(-0.38)$. Six months after the crisis, returns go up even though the large negative returns during the crisis month are included. The mean (median) value of stock returns for a 12-month window is negative. The mean and median values of the $Q$ ratio have a decreasing trend from prior to until after the financial crisis. The mean (median) value of $Q$ decreases from 2.39 (1.87) to 1.56 (1.28) with the financial crisis.

The comparative analyses of performance based on group affiliation and diversification are reported on Panel A. In this panel, we classify affiliated firms by the extent of diversification based on the 2-digit SIC codes assigned to the firms. If the affiliated firms happen to be operating in two or less distinct industries, they are included in group 1 (labelled as Diversified 1) and in more than two distinct industries they are included in group 2 (labelled Diversified 2). Our findings reported in Panel A suggest that non-affiliated firms have a significantly higher export-sales ratio than the affiliated firms. This is valid even though they have a similar import cost ratio and total exposures. The differences in $Q$ and stock returns between these two groups are not statistically significant. This result indicates that, contrary to our expectations, nonaffiliated firms with a higher export-sales ratio did not benefit from the depreciation of the home currency.

We examine the extent of diversification for affiliated firms in order to explore the impact of the group structure in the wake of a currency crisis. Our findings show that firms in the more diversified group 2 (Diversified 2) have a lower mean value of negative total exposure than firms in the less diversified group 1 (Diversified 1). Also these firms have a lower export-sales ratio than non-affiliated firms. In the month of financial crisis, affiliated firms in group 2 are less affected than both affiliated firms in the group 1 and nonaffiliated firms. Moreover, they have higher positive stock market returns 6 months after the crisis month. However, at the end of the 12 -month period, the return differences are not statistically significant. On the other hand, $Q$ ratios of affiliated firms differ when they are separated by the extent of diversification. The more diversified group 2 firms have a lower mean $Q$ ratio than the less diversified group 1 firms. Although this result may seem to contradict the results obtained for the returns, it can be attributed to the higher negative total exposure of the group 1 firms. This group 


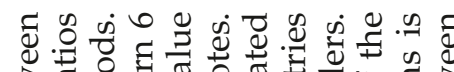

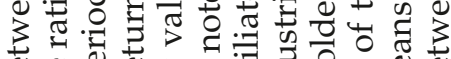

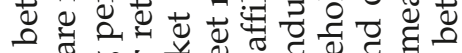

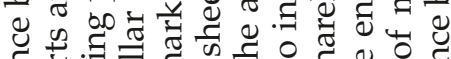

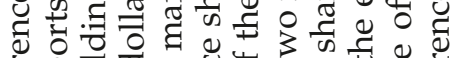

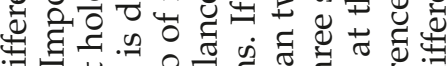

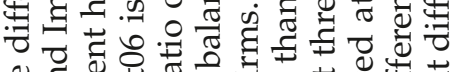

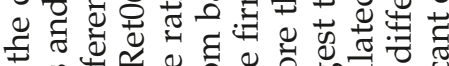

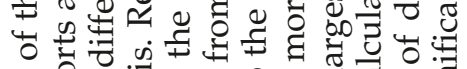

$\circ$ 윰.

전ㄷํ

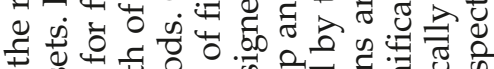

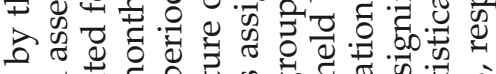

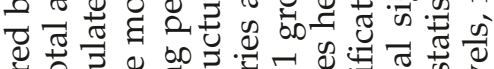

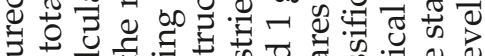

光 +

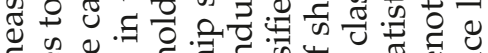

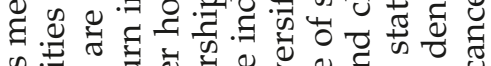

.

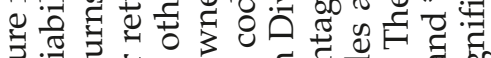

क 크 흐 क0

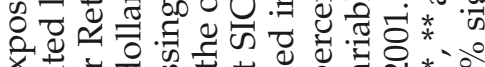

希䒕

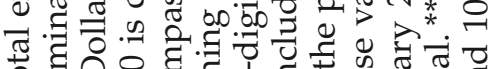

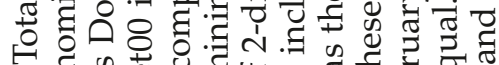

है

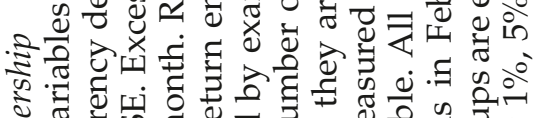

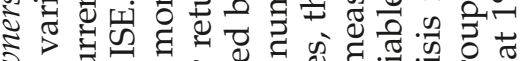

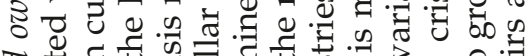

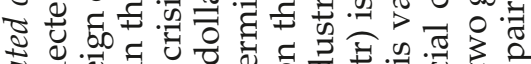

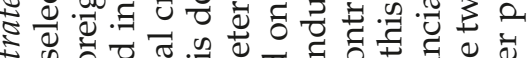

क

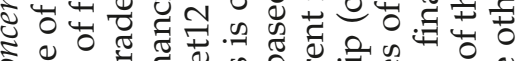

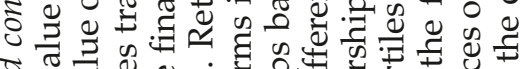

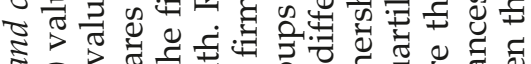

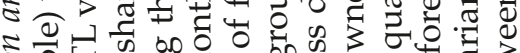

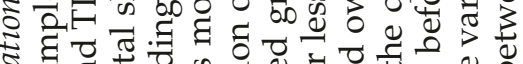

预吉

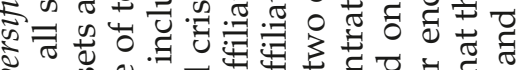

నั

๘

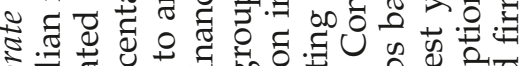

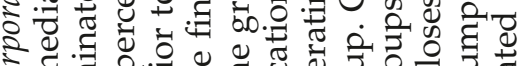

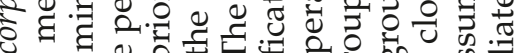

t。

๘

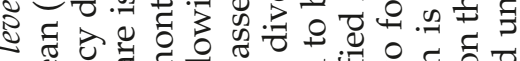

§

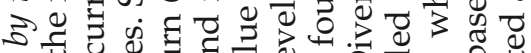

m

के పे ई

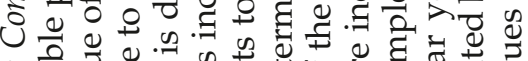

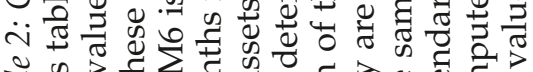

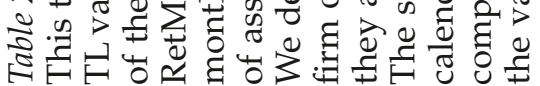

\begin{tabular}{|c|c|c|c|}
\hline \& & ڤొ & 范命 & 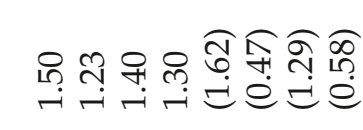 \\
\hline 8 & & 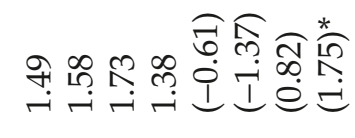 & 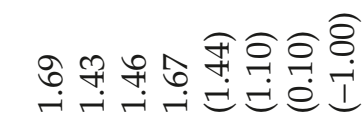 \\
\hline$\sum_{a}^{0}$ & ले & 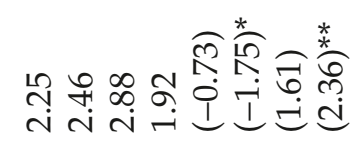 & 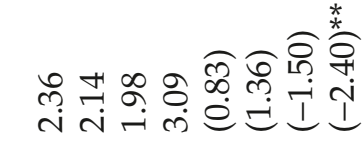 \\
\hline$\stackrel{\Xi}{\overparen{E}}$ & $\begin{array}{ll}9 & 0 \\
0 & 0 \\
0 & 0 \\
0 & 1\end{array}$ & 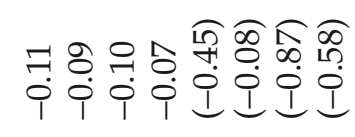 & 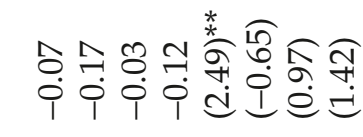 \\
\hline 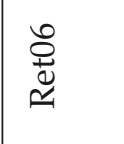 & $\begin{array}{l}8 \\
0 \\
0 \\
0\end{array}$ & 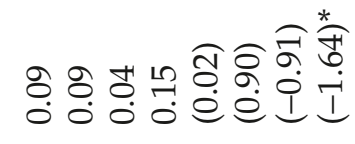 & 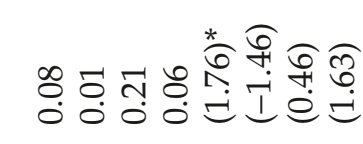 \\
\hline $\begin{array}{l}8 \\
\stackrel{1}{0} \\
\mathscr{2} \\
\simeq\end{array}$ & 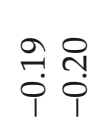 & 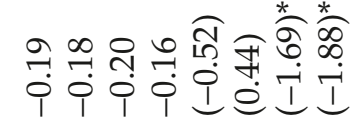 & 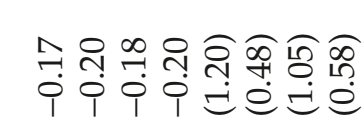 \\
\hline$\sum_{\mathscr{Q}}^{\infty}$ & 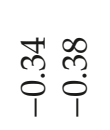 & 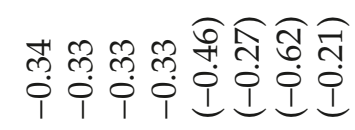 & 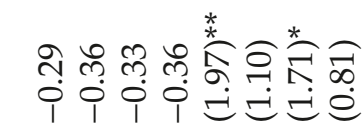 \\
\hline 売 & 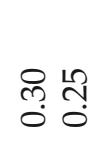 & 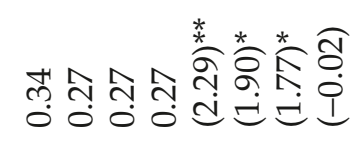 & 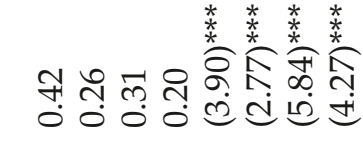 \\
\hline 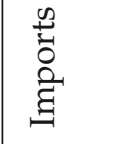 & $\begin{array}{l}\infty \\
\stackrel{\infty}{\hookrightarrow} \\
\dot{0}\end{array}$ & 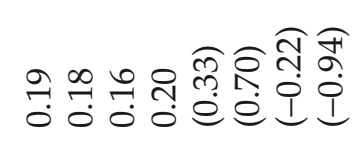 & 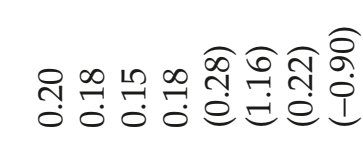 \\
\hline 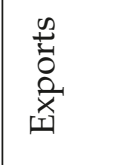 & 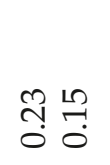 & 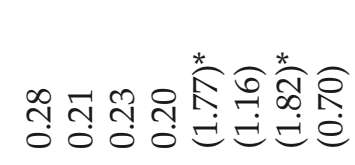 & 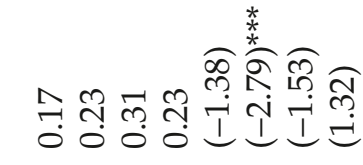 \\
\hline 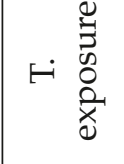 & 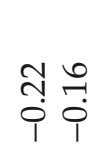 & 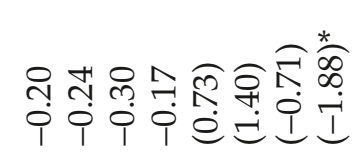 & 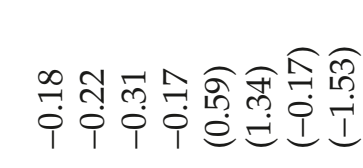 \\
\hline Z & 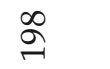 & 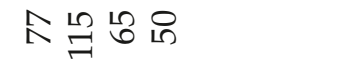 & 유 암요 암 \\
\hline & 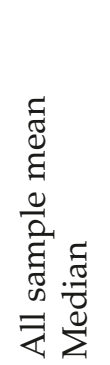 & 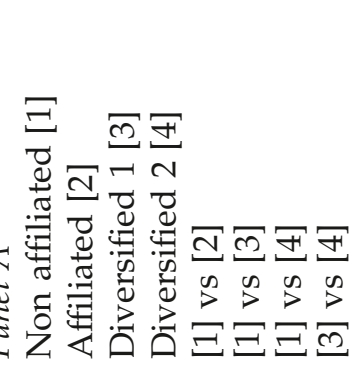 & 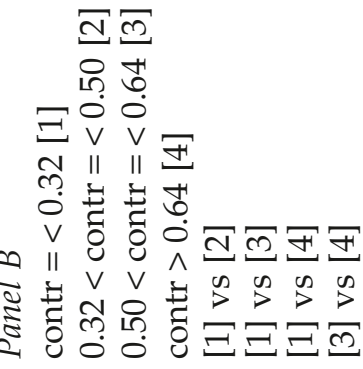 \\
\hline
\end{tabular}


performed better than the group 2 firms during the overvaluation of the Turkish Lira prior to financial crisis, but was hit hard after the crisis. While the $Q$ ratio sharply declined from 2.88 to 1.73 for the less diversified group 1 , it declined more moderately from 1.92 to 1.38 for the more diversified group 2. Despite the sharp decline in the $Q$ ratio of group 1, this group still has a higher average $Q$ ratio than the more diversified group 2 .

On Panel B of Table 2, results are presented based on the ownership concentration. Based on the percentage of shares held by controlling shareholders, the sample is divided into four quartiles. ${ }^{8}$ Even though there are no statistically significant differences in total exposure and the international involvements of firms among these four groups, firms with a lower percentage of concentrated ownership in the first and second quartiles have lower negative stock market returns in the 6 months prior to the crisis including the event month than the firms in the third and fourth quartiles. This result suggests that the concentrated ownership may be a performance determinant prior to and during the crisis period in addition to the total balance sheet exchange rate exposure.

In an effort to explore the impact of the exposure on the performance we classify our firms into high and low exposure groups around the median exposure. Similarly, in order to capture the impact of the international involvement, we classify our sample firms into two categories as "international" and "domestic". Finally we check the impact of the firm size on the performance by grouping the firms around the median size. We report our findings in Table 3. A comparative analysis of the mean value of stock returns suggests that there are significant performance differences among these groups prior to the crisis and during the crisis month.

The results for comparison based on the total exposure (Panel A) indicate that firms with high exposure ${ }^{9}$ have smaller negative returns than firms with low exposure 6 months prior to and in the crisis month. We observe the same results for all four periods for the median return. We also find that large firms (Panel B) perform better than small firms prior to (according to median returns) and during the crisis month (according to both mean and median returns). We have not identified any significant impact of debt exposure (Panel C), the international activities measured by both export-sales (international firms versus domestic firms: Panel D) and import cost ratios (importing versus non-importing firms: Panel E). For the combination of international activities and total exposure, we find that domestic firms with more negative total exposure are affected more during the crisis month (Panel F).$^{10}$ We observe similar results for non-importing firms with more negative total exposure (Panel G).

Comparative analysis of $Q$ ratios indicates that firms with lower debt exposure and higher total exposure (less negative or positive) have a higher $Q 6$ months prior to the crisis month. However, this is reversed 6 months after crisis month. This can be largely attributed to the increasing cash outflows in the aftermath of the crisis due to higher TL cost of servicing foreign currency denominated debt. This reduction of debt values in their balance sheet may reduce dramatically their book value of assets relative to market value. The $Q$ ratios of both international and importing firms are also lower relative to their comparison pairs.

\section{Results from multivariate results}

In this section, we focus on the results from multivariate regression analysis that determine factors having an impact on the firm performance around the crisis. We use several periods for performance, namely adjusted US dollar returns during the crisis month, 6 months prior to and following the crisis. While we are mainly interested in exploring the explanatory power of concentrated ownership and level of group diversification, we control for the exposure, international activity, size and industry. We use four alternative specifications. In model [1] an affiliation dummy is included but industry effect is not controlled. In model [2] industry effect is controlled with the introduction of dummy variables for major industries reported in Table 1. Model [3] introduces dummy variables in order to control the diversification level and the impact of group affiliation. Finally, in Model [4], we use two dummy variables to explore the impact of group diversification of affiliated firms as we exclude the dummy variable to differentiate the affiliated and non-affiliated firms.

Our multivariate regression results are reported in Table 4. Dollar stock return during the crisis month is the dependent variable in Panel A. The estimated coefficient for the Concentrated Ownership is negative and statistically significant. This finding indicates that firms with higher percentage of shares held by large shareholders experience steeper negative stock returns. Group affiliation and group diversification don't have any impact on the stock returns. The coefficient of variables Total Exposure and Export-Sales Ratio are positive and statistically significant at 1 percent level in all four regression models. This result suggests that firms with lower negative or 


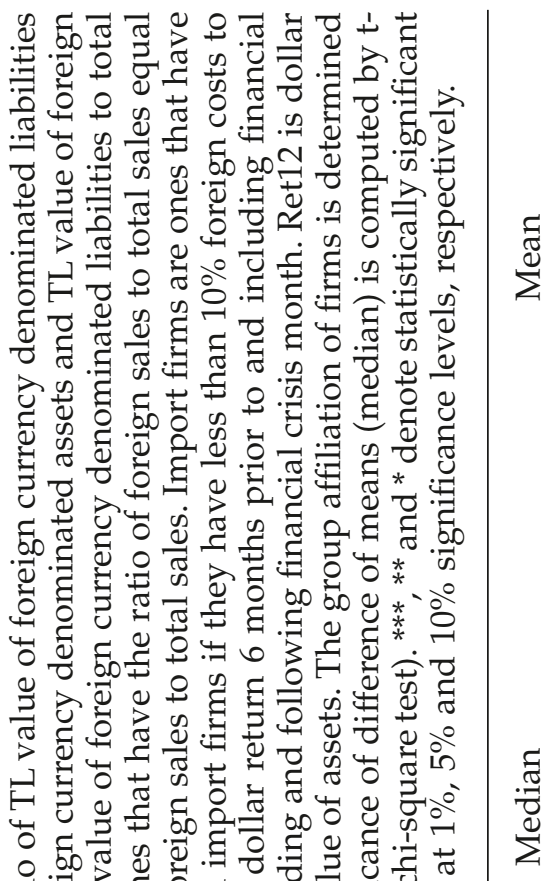

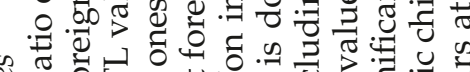

\&

.

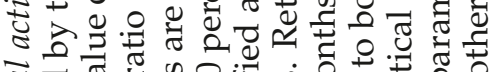

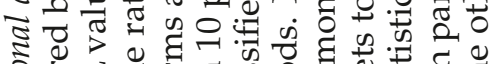

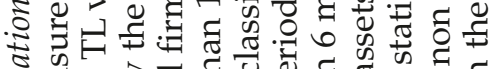

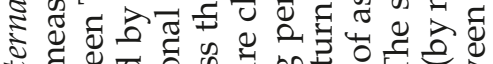

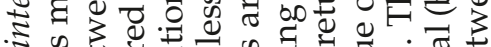

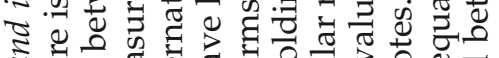

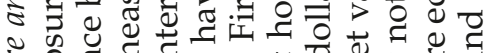

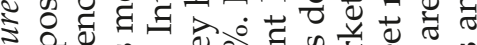
के

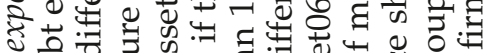
एँ

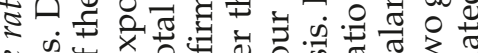

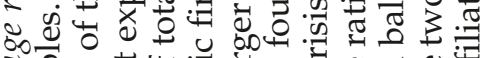
ㅎ. 웜유

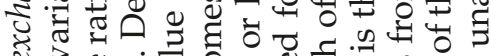

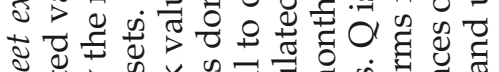
¿

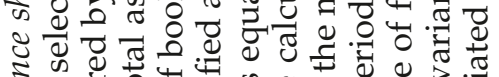
ह ₹ 0 क पूँ

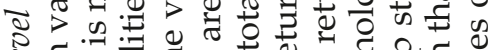

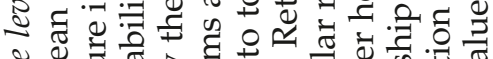

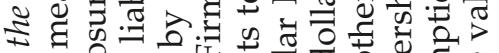
$\rightarrow$ 웡

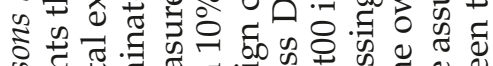
. है نे 0

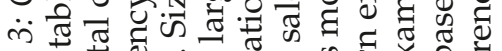

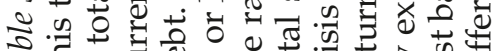

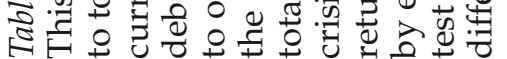

$\overbrace{\Sigma}^{\approx}$
व.

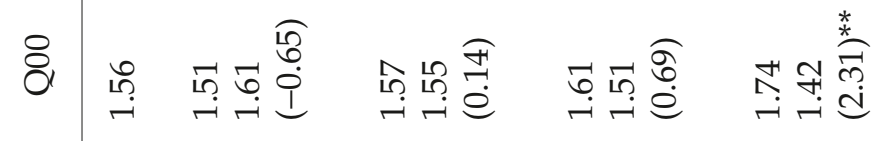

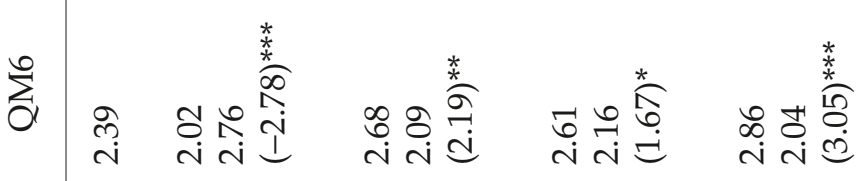

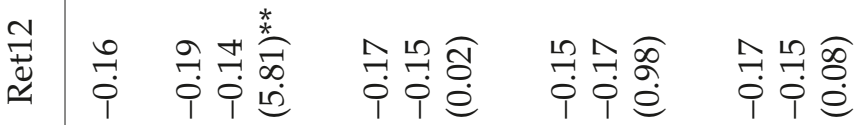

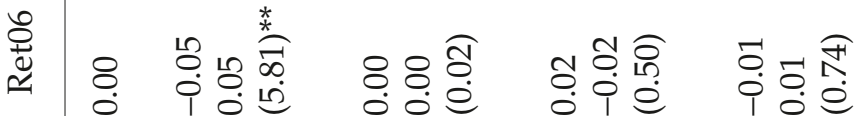

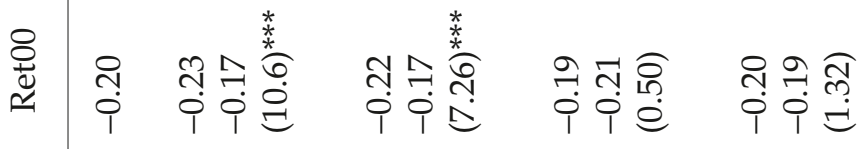

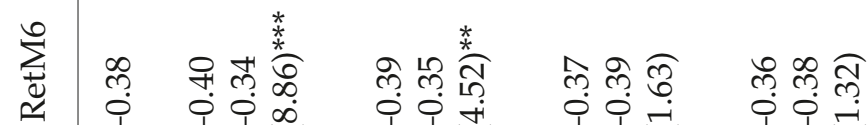

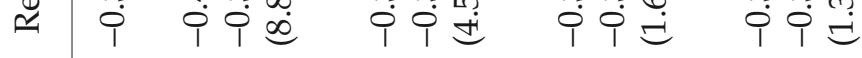

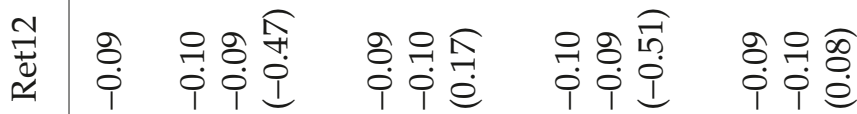

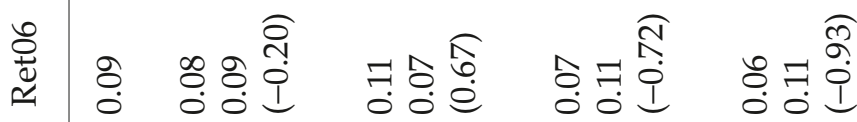

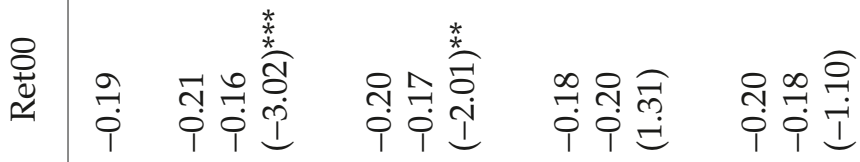

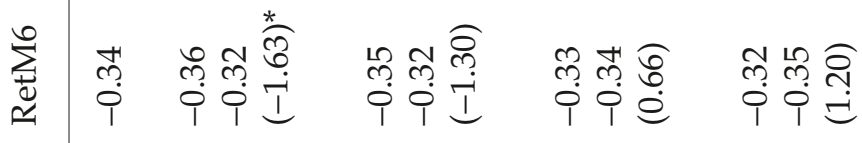

๙

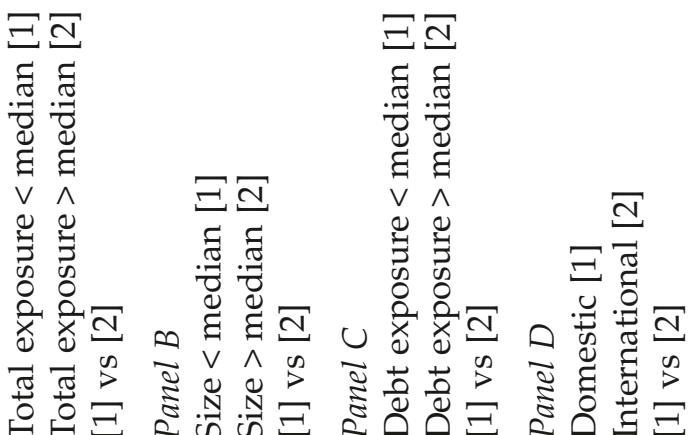




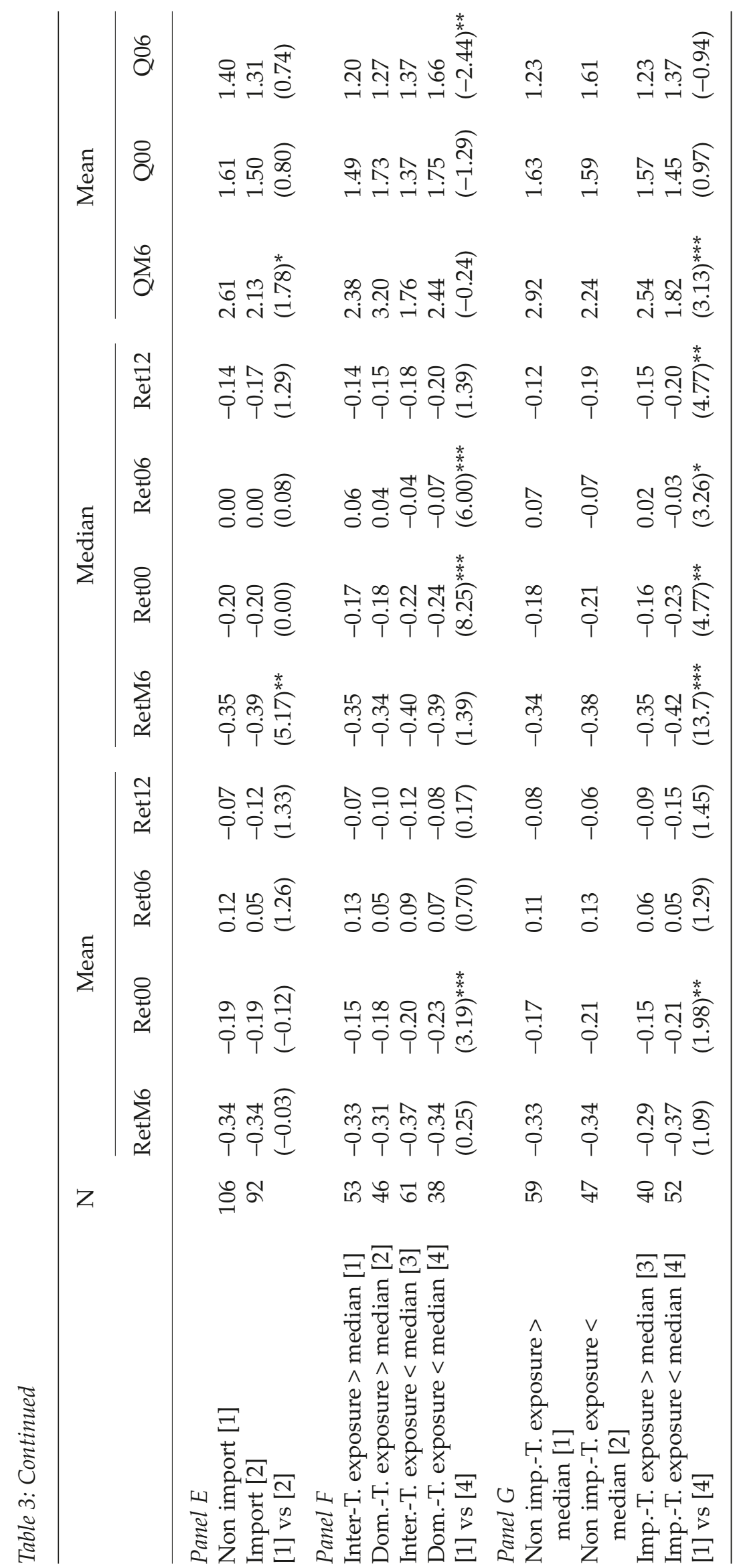




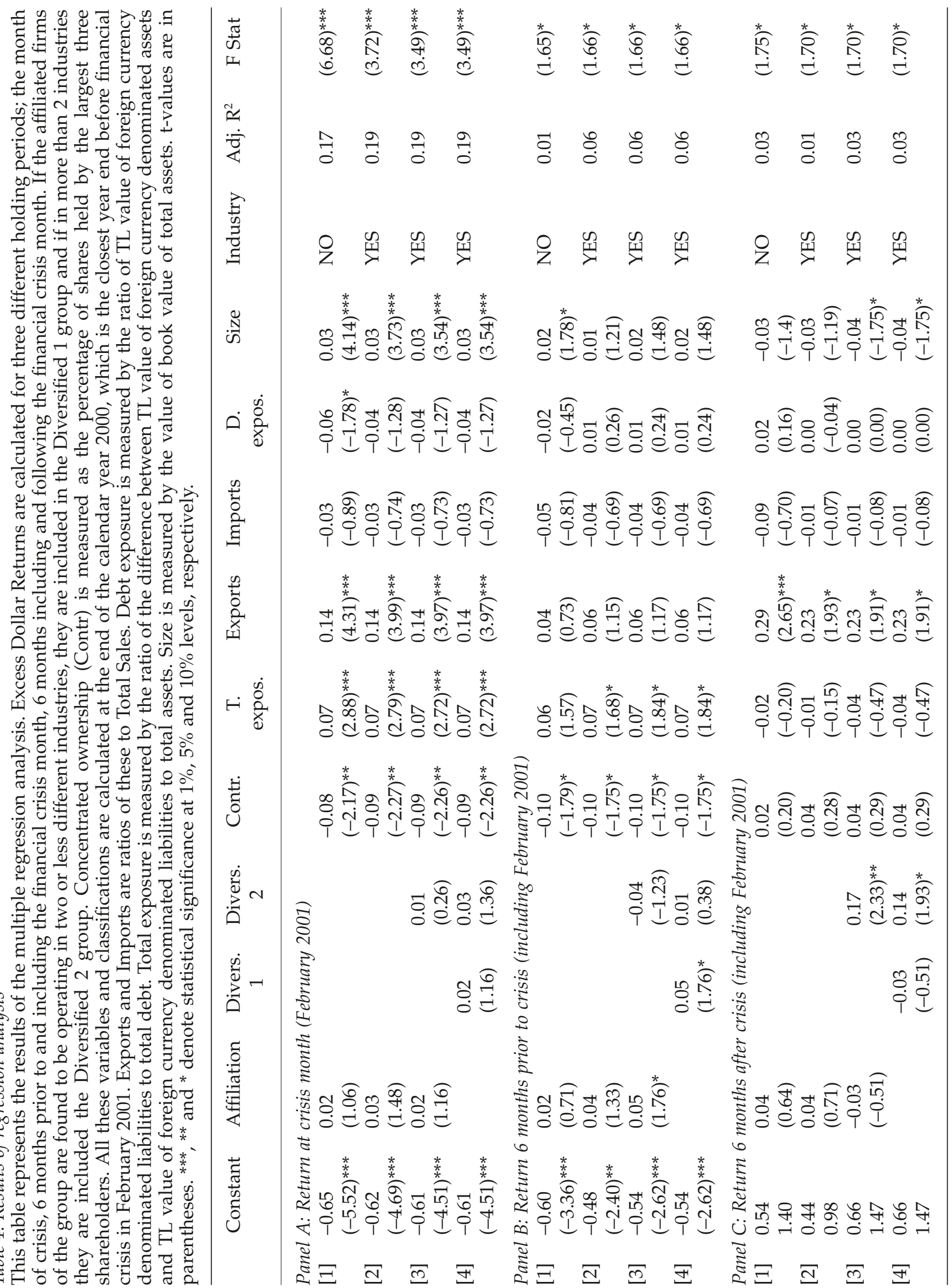


positive exposures or firms with higher exports have higher stock returns (less negative) in the crisis month. We also observe that debt exposure does not have any effects on stock returns by itself. We interpret the evidence on total exposure and debt exposure together, since exchange rate risk at firm level depends on the combination of assets and liabilities. The positive sign observed in the variable Size suggests that decline in value is larger for small firms than for large firms.

In Panel B, return 6 months prior to crisis is the dependent variable. Our results reported here are similar to results in Panel A with the exception of Export-Sales Ratio. However, significance levels are lower in this case. The firms with a higher export-sales ratio don't have significantly different returns than the firms with lower export-sales ratio during this period. The estimated coefficient of the dummy variable for the less diversified business group firms is significantly positive in the regression Model 4. Since this group of firms has higher negative total exposures, they experience higher stock returns before the crisis when TL is overvalued. The results for the adjusted holding period return 6 months following the crisis (Panel C) indicate that firms with higher exports have higher stock returns after sharp devaluations. Moreover, stock returns at this period are higher for more diversified business group firms (Diversified 2). The estimated coefficients of this variable are positive at both Models 3 and 4 . Total exposure and Concentrated Ownership don't have any impact on the results for this period.

\section{Concluding remarks}

In this article, we analyse the impact of concentrated ownership and group affiliation on the performance of 198 Turkish industrial firms in adversity. The study focuses on and around the 2001 financial crisis. Our analysis controls for firm-specific currency exposure, international activities, and size. We measure the firm-level foreign exchange rate exposure by using an accounting measure, namely balance sheet exchange rate exposure. This measure is a more robust risk measure than the ones used in the related literature.

We show that stock returns 6 months prior to and during financial crisis decrease dramatically, but after crisis period returns are recovered. Our results provide evidence that ownership concentration is the main determinant of the firm value during a crisis period along with the balance sheet exposure, size and export-sales ratio. Concentrated ownership is associated with significantly lower return performance, especially prior to and during financial crisis. This is the period investors are disappointed by lower returns. Lower returns trigger an excessive expropriation activity by controlling shareholders. We observe that the adjusted returns are positively associated with total exposure, firm size and export-sales ratio. While business group affiliation does not seem to have any effect on returns, the findings provide weak evidence for a positive association between the group diversification and performance.

\section{Notes}

1. They also measure firm risk with Beta which is obtained from the market model regression performed with one year daily stock returns during the 1996 period.

2. The size of the primary markets is very small compared with peers and developed economies.

3. Persistent budget deficits in the Turkish economy created an insatiable desire for funds and crowded out private firms from the bond market.

4. This is evident in many high profile expropriations in the 1990s by insiders or majority controlling shareholders, e.g. Metas and Cukurova Electric. It is also verified by the scores and rankings attributed to Turkey in La Porta et al. (1998).

5. T.C. Central bank reports monthly real exchange rate index normalised in the year 1995. The overvaluation of Turkis Lira can easily be observed by examining this index (http:/ /tcmbf40.tcmb.gov.tr/cbt.html).

6. However, these firms may not be able generate sufficient export sales (foreign currency cash flows) during the crisis period and in its aftermath partly because of deteriorating supply conditions, and disruptions in the domestic credit markets. These factors may have a negative impact on their performance.

7. It is possible that hedging losses incurred during the devaluation period may offset otherwise possible windfall gains from exports. However, most widely available hedging tools are short-term in nature, and unless the firm engages in operational hedges, the impact of these losses on the firm value may be limited.

8. All firms in the sample were divided into four quartiles based on the level of concentration: 0-32, 32-50, 50-64, >64 percent.

9. High exposure means total exposure above the median, less negative or positive.

10. More negative means a larger difference between the TL value of the foreign currency denominated debt and the TL value of foreign currency denominated assets. 


\section{References}

Baek, J., Kang, J. and Park, K. S. (2004) Corporate Governance and Firm Value: Evidence from the Korean Financial Crisis, Journal of Financial Economics, 71, 265-313.

Calvo, G. and Reinhart, C. (2000) Fixing for your Life. NBER working paper no. 8006.

Desai, M. A., Foley, C. F. and Forbes, K. (2003) Multinational and Local Firm Responses to Currency Crisis. Working paper.

Forbes, K. (2002) How Do Large Depreciations Affect Firm Performance, IMF Staff Papers, 49, 214-238.

Glen, J. (2002) Devaluations and Emerging Stock Market Returns, Emerging Markets Review, 3, 409428.

Johnson, S., Boone, P., Breach, A. and Friedman, E. (2000) Corporate Governance in the Asian Financial Crisis, 1997-98, Journal of Financial Economics, 58, 141-186.

Kim, B. and Lee, I. (2003) Agency Problems and Performance of Korean Companies During the Asian Financial Crisis: Chaebol vs. Non-Chaebol Firms, Pacific-Basin Journal, 11, 327-348.

La Porta, R., Lopez de Silanez, F., Shleifer, A. and Vishny, R. (1998) Law and Finance, Journal of Political Economy, 106, 1113-1156.
Lemmon, M. L. and Lins, K. V. (2003) Ownership Structure, Corporate Governance, and Firm Value: Evidence from the East Asian Financial Crisis, Journal of Finance, 58, 1445-1468.

Mitton, T. (2002) A Cross-firm Analysis of the Impact of Corporate Governance on the East Asian Financial Crisis, Journal of Financial Economics, 20, 293-315.

Shleifer, A. and Vishny, R. (1997) A Survey of Corporate Governance, Journal of Finance, 52, 737-783.

Halit Gonenc is Research Fellow at the Faculty of Management and Organization and SOM Research School, University of Groningen in the Netherlands. He obtained his $\mathrm{PhD}$ in Finance from Old Dominion University, USA in 1999.

C. Bulent Aybar is Professor of International Finance at Southern New Hampshire's School of Business. His main teaching and research interests are in FX risk management, emerging capital markets, international mergers and acquisitions and privatization. He holds a PhD from Fisher College of Business at Ohio State University. 